\title{
Peran Guru Kelas Pada Pelaksanaan Bimbingan Konseling Dalam Menumbuhkan Sikap Tanggung Jawab Di SD Negeri 1 Pamijen
}

\author{
Dilla Tiara Kusuma Dewi ${ }^{1}$ \\ 1)Pendidikan Guru Sekolah Dasar; Universitas Muhammadiyah Purwokerto; \\ dillatiara00@gmail.com
}

\begin{abstract}
Abstrak. Penelitian ini bertujuan untuk mengetahui peran guru kelas pada pelaksanaan layanan Bimbingan Konseling dalam menumbuhkan sikap tangggung jawab peserta didik. Penelitian ini menggunakan penelitian kualitatif dengan jenis penelitian deskripsi dengan partisipan kepala sekolah, guru kelas, dan peserta didik. Teknik pengumpulan data menggunakan wawancara, observasi, dan dokumentasi. Analisis yang digunakan dalam penelitian ini yaitu mengolah data mentah dan mempersiapkan data untuk dianalisi (verbatim), membaca data secara keseluruhan dan mengkodingnya (horizon), memasukan data ke dalam tema-tema atau deskripsi (cluster meaning) dan menganalisis data menjadi hasil penelitian. Keabsahan data menggunakan teknik triangulasi sumber, waktu, dan teknik. Hasil penelitian menunjukn peran guru kelas pada pelaksanaan layanan Bimbingan Konseling dalam menumbuhkan sikap tanggung jawab peserta didik yaitu memberikan motivasi, memberikan nasehat, memberikan contoh, memberikan hukuman, membimbing, dan mengkoreksi. Pelaksanaan Bimbingan Konseling yang dilakukan oleh guru kelas dapat membuat peserta didik melaksanakan sikap tanggung jawab, seperti berangkat tepat waktu, mengerjakan PR secara berkelompok, melaksanakan tugas piket, memakai seragam sesuai aturan, dan bertanggung jawab pada segala perbuatan yang dilakukan.
\end{abstract}

Kata kunci: Bimbingan Konseling; peran guru kelas; sikap tanggung jawab; peserta didik.

\section{Pendahuluan}

Pendidikan merupakan usaha sadar yang dilakukan oleh manusia untuk meningkatkan taraf hidupnya dan menjadi manusia yang lebih baik, baik dari segi pengetahuan maupun sikap. Pendidikan menjadi langkah awal untuk kesuksesan seseorang. Pendidikan tidak hanya memberikan ilmu pengetahuan namun pendidikan dapat membentuk sikap pada peserta didik, seperti yang tercantum dalam Undang-undang Republik Indonesia nomor 20 Tahun 2003 Pasal 3 tentang Sistem Pendidikan Nasional disebutkan bahwa: 
"Pendidikan Nasional berfungsi mengembangkan kemampuan dan membentuk watak serta peradaban bangsa yang bermartabat dalam rangka mencerdaskan kehidupan bangsa, bertujuan untuk berkembangnya potensi peserta didik agar menjadi manusia beriman dan bertakwa kepada Tuhan Yang Maha Esa, berakhlak mulia, sehat, berilmu, cakap, kreatif, mandiri, dan menjadi warga negara yang demokratis serta bertanggung jawab".

Undang-undang diatas menyatakan bahwa pendidikan tidak terlepas dari pembentukan sikap bagi peserta didik untuk menjadi lebih baik. Pembelajaran di sekolah tidak hanya seputar pengetahuan, namun pembentukan sikap pada peserta didik menjadi hal yang penting bagi sebuah sekolah. Pembentukan sikap pada peseta didik dianggap penting terutama dalam menumbuhkan sikap tanggung jawab.

Tanggung jawab merupakan sikap yang sangat penting dalam dunia pendidikan dan sebagai bekal peserta didik untuk hidup di masyarakat. Pentingnya menumbuhkan sikap tanggung jawab sangat mempengaruhi prestasi dan sikap peserta didik di rumah dan di sekolah. Sekolah Dasar menjadi tempat dalam menumbuhkan sikap tanggung jawab khususnya untuk peserta didik yang termasuk dalam masa perkembangan. Menurut Mumpuni (2018:27) tanggung jawab merupakan karakter yang dimiliki oleh seseorang untuk melaksanakan tugas dan kewajiban yang seharusnya dilakukan baik terhadap diri sendiri, masyarakat, lingkungan dan Tuhan. Tanggung jawab tidak hanya pada diri sendiri, namun tanggung jawab harus dilakukan pada segala hal yang menyangkut kehidupan manusia.

Peran guru kelas dan orang dalam menanamkan sikap tanggung jawab sangat penting untuk menunjang kehidupannya dalam masyarakat. Menurut jurnal penelitian yang dilakukan oleh Sylvia Anggraeni tentang Pembentukan Sikap Tanggung Jawab Di Sekolah Kreatif SD Muhammadiyah Bayan Kabupaten Purworejo. Hasil penelitian menunjukan bahwa pembentukan sikap tanggung jawab yang dilakukan dengan memberikan pengalaman baru, pemberian keteladanan, pemberian sugesti positif, kegiatan identifikasi sikap, dan pemberian hukuman. Pembentukan sikap tanggung jawab pada peserta didik dapat dilakukan dengan berbagai cara dan pihak sekolah menjadi faktor penting dalam menumbuhkan sikap tanggung jawab.

Beradasarkan hasil observasi awal yang dilakukan di SD Negeri 1 Pamijen. Peneliti menemukan peserta didik yang menunjukan sikap tanggung jawab yang diajarkan oleh guru kelas dalam pelaksanaan layanan Bimbingan Konseling. Menurut jurnal peneltitian yang dilakukan oleh Emily 
Scott dkk (2016) dengan judul School Couseling Faculty Perceptions and Experiences Preparing Elementary School Counselor. Hasil penelitian tersebut menunjukan bahwa pelaksanan Bimbingan Konseling yang dilakukan di Sekolah Dasar penting untuk dilakukan. Bimbingan Konseling di Sekolah Dasar memberikan fondasi penting bagi kehidupannya. Pelaksanaan Bimbingan Konseling di SD N 1 Pamijen dalam menumbuhkan sikap tanggung jawab pada peserta didik terlihat dengan adanya peserta didik memakai seragam sesuai jadwal, mengerjakan PR dengan baik, membuang sampah pada tempatnya, dan melaksanakan piket. Berdasarkan observasi awal dan wawancara yang dilakukan oleh peneliti terhadap guru kelas tinggi, kelas rendah, dan kepala sekolah tersebut menunjukan bahwa sikap tanggung jawab peserta didik pada SD Negeri 1 Pamijen mulai membaik dengan adanya Bimbingan Konseling.

\section{Metode Penelitian}

Penelitian ini dilakukan di SD Negeri 1 Pamijen Kecamatan Sokaraja Kabupaten Banyumas. Guru kelas bertugas memberikan pengetahuan terkait dengan pembelajaran dan memberikan layanan Bimbingan Konseling untuk menumbuhkan sikap tanggung jawab pada peserta didik. Penelitian ini menggunakan penelitian kualitatif Menurut Creswell (2013: 264) penelitian kualitatif merupakan penelitian interpretif, artinya peneliti terlibat dalam pengalaman yang berkelanjutan dan terus menerus dengan para partisipan. Pengumpulan data yang dilakukan oleh peneliti dengan melakukan wawancara, observasi dan dokumentasi. Teknik analisis data yang dilakukan dalam penelitian ini seperti, mengolah dan mempersiapkan data untuk dianalisis, membaca keseluruhan data, menganalisis lebih detail dengan meng-coding, proses coding, deskripsi disajikan dalam bentuk narasi, dan menginterprentasikan. Uji keabsahan data menggunakan teknik triangulasi yaitu triangulasi sumber, triangulasi teknik, dan triangulasi waktu.

\section{Hasil Penelitian Dan Pembahasan}

\section{Hasail Penelitian}

\section{A. Peran Guru Kelas Pada Pelaksanaan Layanan Bimbingan Konseling dalam Menumbuhkan Sikap Tanggung Jawab Peserta Didik}

\section{Membimbing}

Bimbingan yang dilakukan oleh guru berupa bimbingan belajar dan bimbingan dalam menumbuhkan sikap tanggung jawab. Guru memberikan bimbingan belajar pada peserta didik yang kurang berprestasi pada jam istirahat dan pulang sekolah. Bimbingan guru 
dalam menumbuhkan sikap tanggung jawab dengan selalu mengajarkan sikap tanggung jawab.

2. Mengingatkan

Guru mengingatkan peserta didik dalam menumbuhkan sikap tanggung jawab pada pembelajaran dan diluar pembelajaran. Guru kelas dua mengingatkan peserta didik pada hal-hal yang sederhana seperti membuang sampah pada tempatnya, guru kelas lima mengingatkan peserta didik dengan hal-hal yang lebih berat seperti bertanggung jawab pada setiap perbuatana yang dilakukan.

3. Memberikan Nasehat

Guru memberikan nasehat pada pembelajaran dan diluar pembelajaran, seperti jam istirahat dan saat akan pulang. Pemberian nasehat yang dilakukan sebagai salah satu bentuk kepedulian guru pada peserta didik. Guru kelas memberikan nasehat pada peserta didik untuk mentaati peraturan sekolah, sebagai salah satu bentuk menumbuhkan sikap tanggung jawab.

4. Memberikan Hukuman

Guru memberikan hukuman pada peserta didik yang melanggar aturan sekolah dan tidak melaksanakan sikap tanggung jawab. Guru menerapkan sistem denda dan buku kasus untuk menghuku peserta didik. Peserta didik yang tidak mengerjakan PR akan dihukum untuk mengerjakan PR diluar kelas.

5. Korektor

Guru menjadi korektor pada pelaksanaan sikap tanggung jawab pada peserta didik dengan memberikan nasehat ketika menemukan peserta didik yang melanggar aturan dan memberikan pujian pada peserta didik yang melaksanakan sikap tanggung jawab. Guru menjadi korektor dan memberikan penilaian untuk peserta didik dalam sikap tanggung jawab.

6. Memberikan Motivasi

Pemberian motivasi yang dilakukan guru berkaitan dengan akademik dan pembentukan sikap tanggung jawab. motivasi dalam bidang akademik yang diberikan guru seperti, selalu mengerjakan PR dan selalu belajar dirumah.

7. Memberikan Contoh

Guru sebagai pelaksana Bimbingan Konseling dalam sikap tanggung jawab dengan memberikan contoh. Guru kelas dua memberikan contoh pada peserta didik dengan menerapkan hal-hal yang sederhana seperti, memakai seragam sesuai aturan, berangkat 
tepat waktu, dan melaksanakan tugas piket. Guru kelas lima memberikan contoh pada peserta didik dengan selalu bertanggung jawab pada perbuatan yang dilakukan.

\section{Pembahasan}

Guru memiliki peran ganda yang harus dilakukan yaitu sebagai pemberi materi dan sebagai pelakanan Bimbingan Konseling. Pelaksanaan Bimbingan Konseling, di SD N 1 Pamijen dilakukan oleh guru kelas. Menurut Syaiful (2009:44-48) peran guru selain menyampakan materi terdapat peran lain seperti, sebagai korektor, inspirator, motivator, fasilitator, pembimbing, dan evaluator. Adanya latar belakang peserta didik yang kebanyak orang tua berkerja di luar daerah dan luar negeri sehingga guru-guru dari SD tersebut perlu untuk menerapkan Bimbingan Konseling. Tujuan Bimbingan Konseling yang diterapkan oleh guru-guru untuk membentuk peserta didik menjadi lebih baik, terutama dalam mentaati peraturan yang ada di sekolah tersebut dan menumbuhkan sikap tanggung jawab sejak dini. Menurut jurnal penelitian Umi Larasati (2016) tentang Peran Guru Sebagai Pelaksanan Layanan Bimbingan Konseling dalam Menumbuhkan Sikap Disiplin Siswa di SD N Keputeran 2 Yogyakarta. Hasil penelitian menunjukan bahwa peran guru kelas pada pelaksanaan layanan Bimbingan Konseling berperan dalam membimbing, memberikan nasehat, memberikan teguran, memberikan pujian, memberikan hukuman, memberikan contoh, sebagai fasilitatof, bekerjasama dengan orang tua, kepala sekolah, dan sesama guru, dan memberikan motivasi. Pelaksanan Bimbingan Konseling yang dilakukan guru di SD N 1 Pamijen dalam menumbuhkan sikap tanggung jawab pada peserta didik seperti, memberikan nasehat, memberikan bimbingan, memberikan motivasi, memberikan contoh, memberikan koreksi, menghukum, dan mengingatkan.

Sikap tanggung jawab sangat penting ditanamkan sejak dini oleh guru dan orang tua. Menurut Mutasir (2017:9) tanggung jawab merupakan sikap dan perilaku seseorang untuk melaksanakan tugas dan kewajibannya sebagaimana yang harus dilakukan, terhadap diri sendiri, masyarakat, lingkungan (alam, social, dan budaya), Negara dan Tuhan. Tanggung jawab manusia tidak hanya pada diri sendiri, namun pada segala sesuatu yang berkaitan dengan hidupnya seperti, masyarakat, lingkungan, Negara, pekerjaan, dan Tuhan. Manusia harus mempertanggung jawabkan segala perbuatannya, baik negatif maupun positif dan dapat menjadi contoh manusia yang lain dalam kehidupan bermasyarakat.

Berdasarkan jurnal penelitian yang dilakukan oleh Semra Kirani Gungor dkk (2017) dengan judul The Education Of Developing Responsibility 
Value. Hasil penelitian menunjukan bahwa peserta didik melaksanakan sikap tanggung jawab dengan mealukan hal-hal yang sederhan yang di terapkan di sekolah dan di rumah, seperti tanggung jawab pada diri sendiri, hewan peliharaan, tetangga, kakak/adik, guru, dan orang tua. Pelaksanaan sikap tanggung jawab peserta didik SD N 1 Pamijen dengan menerapkan hal-hal yang sederhana seperti mengerjakan PR, melaksanakan piket, membuang sampah pada tempatnya, bertanggung jawab pada perbuatan yang dilakukan, memakai seragam sesuai aturan, dan berangkat tepat waktu.

\section{A. Peran Guru Kelas Pada Pelaksanaan Layanan Bimbingan Konseling dalam Menumbuhkan Sikap Tanggung Jawab Peserta Didik}

\section{Membimbing}

Guru melakukan bimbingan kepada peserta didik yang membutuhkan baik dalam bimbingan belajar maupun dalam pembentukan sikap tanggung jawab. Pada bimbingan belajar guru melakukan pada peserta didik yang dianggapnya kurang dalam akademik, salah satu contohnya guru kelas dua memberikan bimbingan pada peserta didik yang belum lancar dalam membaca. Guru kelas dua melakukan bimbingan pada saat jam istirahat dan setelah pulang sekolah selama 15-30 menit. Guru kelas lima melakukan bimbingan pada peserta didik yang dianggap kurang dalam akademik, terutama dalam pelajaran matematika.

2. Mengingatkan

Pembentukan sikap tanggung jawab guru mengajarkan hal-hal yang sederhana terutama pada kelas dua, yang masih tergolong kelas rendah dan masih butuh perhatian besar. Pada kelas lima guru mengajarkan hal-hal yang berbeda dengan kelas dua seperti selalu bertanggung jawab pada setiap perbuatan dan dilakukannya dan selalu melatih peserta didik untuk mengerjakan PR secara berkelompok. Guru kelas dua dan kelang lima selalu mengingatkan peserta didik pada jam pelajaran dan di luar jam pelajaran seperti, pada jam istirahat dan ketika pulang.

3. Memberikan Nasehat

Peran guru dalam memberikan nasehat untuk peserta didik dilakukan pada pembelajaran dan diluar pembelajaran. Guru memberikan nasehat sebagai salah satu bentuk kepedulian guru terhadap peserta didik dan untuk melatih sikap tanggung jawab peserta didik. Sikap tanggung jawab yang diajarkan oleh guru seperti selalu berangkat tepat waktu, membuang sampah pada tempatnya, mengerjakan PR, memakai seragam sesuai aturan, melakukan tugas 
piket, mengerjakan tugas kelompok secara bersama-sama, dan selalu bertanggung jawab pada setiap perbuatan yang dilakukan.

4. Memberikan Hukuman

Guru sebagai pelaksanan layanan Bimbingan Konseling dalam menumbuhkan sikap tanggung jawab pada peserta didik yaitu dengan memberikan hukuman pada peserta didik yang melanggar aturan sekolah dan tidak melaksanakan sikap tanggung jawab. Guru kelas dua dan kelas lima tidak pernah memberikan hukuman pada peserta didik dengan fisik. Pada kelas dua terdapat buku kasus yang dikelola oleh guru kelas, buku kasus ini merupakan buku untuk mencatat segala pelanggaran yang dilakukan peserta didik seperti, tidak melaksanakan tugas piket, tidak mengerjakan PR, dan tidak membawa buku LKS. Peserta didik yang melanggar aturan sekolah disuruh untuk menuliskan di buku kasus dan berdiri di depan kelas untuk difoto guru. Foto tersebut akan ditunjukan pada orang tua ketika pengambilan rapot, sehingga orang tua mengetahui perkembangan sikap anaknya. Pada kelas lima terdapat sistem denda yang dikelola oleh guru kelas dan bendahara kelas. Sistem denda yang diterakan oleh guru kelas untuk mengurangi peserta didik melakukan pelanggaran peraturan sekolah dan tidak melaksanakan sikap tanggung jawab. Peserta didik akan diberi denda sesuai dengan pelanggaran yang dilakukan, seperti tidak mengerjakan PR secara berkelompok akan didenda. Uang dari hasil denda tersebut digunakan untuk kepentingan bersama seperti untuk transport pada kegiatan diluar sekolah. Adanya sistem denda dapat membuat efek jera pada peserta didik, sehingga peserta didik tidak melakukan pelanggaran kembali.

5. Korektor

Peran guru kelas dalam pelaksanaan layanan Bimbingan Konseling dalam menumbuhkan sikap tanggung jawab peserta didik, salah satunya dapat menjadi korektor untuk peserta didik. Guru dapat menilai peserta didik yang telah melaksanakan sikap tanggung jawab dan yang belum melaksanakan sikap tanggung jawab. Peserta didik yang tidak melaksanakan sikap tanggung jawab, akan diberikan nasehat dan peserta didik yang telah melaksanaan sikap tanggung jawab guru akan memberikan pujian.

6. Motivasi

Motivasi yang diberikan guru berkaitan dengan akademik dan pembentukan sikap tanggung jawab. Pada pelaksanaannya guru memberikan motivasi pada peserta didik pada saat pembelajaran atau 
di luar pembelajaran, sesuai dengan keadaan peserta didik. Berdasarkan observasi Guru selalu memberikan motivasi untuk tidak melanggar aturan sekolah pada peserta didik dan memberikan motivasi pada pembelajaran yang dilakukan. Salah satu contoh motivasi yang guru lakukan dalam pembelajaran yaitu dengan memberikan dorongan-dorongan untuk selalu mengerjakan PR dan selalu belajar di rumah.

7. Memberikan Contoh

Guru selalu memberikan contoh yang baik-baik dan sederhana pada peserta didik, sehingga dapat dipraktekan di sekolah dan di rumah. Hal-hal yang ditanamkan oleh guru kelas dua dalam memberikan contoh untuk peserta didik seperti selalu berpakaian sesuai aturan, berangkat tepat waktu, melaksanakan piket, dan membuang sampah pada tempatnya. Pada kelas lima guru memberikan contoh pada peserta didik pada sikap tanggung jawab dengan selalu bertanggung jawab pada segala perbuatan yang dilakukan, melaksanakan kebersihan secara bersama-sama, dan berlaku sopan santun terhadap siapapun di rumah dan di sekolah. Pemberian contoh yang berbeda antara kelas dua dan kelas lima dilakukan oleh guru dengan menyesuaikan perkembangan peserta didik dan tingkat kelasnya.

\section{Simpulan}

Bimbingan konseling yang dilakukan oleh guru dengan cara memberikan nasehat, memberikan motivasi, memberikan contoh, memberikan koreksi atau penilaian, membimbing, mengingatkan, dan memberikan hukuman kepada peserta didik. Salah satu contoh terlaksanan Bimbingan Konseling telah diterapkan di sekolah tersebut adanya peserta didik yang telah melaksanakan sikap tanggung jawab seperti mengrjaka PR, berangkat tepat waktu, memakai seragam sesuai aturan, mengerjakan PR secara berkelompok, dan bertanggung jawab pada setiap perbuatan yang dilakukan.

\section{Ucapan Terima Kasih}

Puji syukur saya panjatkan kepada Allah SWT yang telah melimpahkan banyak anugerah dan segala kuasaNya disetiap perjalanan hidup saya, sehingga dapat menyelesaikan artikel ini. Artikel ini saya persembahkan kepada orang yang telah menginspirasi peneliti:

1. Kedua orang tua saya dan keluarga besar yang saya hormati dan saya cintai terimakasih atas seluruh kasih sayang, pengorban, motivasi dan do'a yang tiada hentinya kalian berikan. 
2. Dosen pembimbing yang telah membimbing, memberikan informasi, dan memberika motivasi.

3. Kepada Caruban yang telah bersedia untuk mempublikasikan artikel ini.

4. Teman-teman yang telah memberikan motivasi dalam pembuatan artikel ini.

\section{Daftar Pustaka}

Creswell. J.W. (2013). Research Design Pendekatan Kualitatif, Kuantitatif, dan Mixed. Pustaka Pelajar: Yogyakarta.

Djamnah. S. B. (2009). Guru dan Anak Didik dalam Interaksi Edukasi. PT Remaja Rosdakarya.

Emily. S.G ddk. 2016. School Counseling Faculty Perceptions and Experiences Preparing Elementary School Counselors. The Profesional Counselor, 6 (4).

Larasati. U. (2016). Peran Guru Sebagai Pelaksana Layanan Bimbingan Konseling dalam Membangun Sikap Disiplin Peserta didik di SD Negeri Keputeran 2 Yogyakarta Tahun Ajaran 2015/2016. Jurnal Pendidikan KeSDan. 3(1).

Mumpuni. A. (2018). Integrasi Nilai Karakter Dalam Buku Pelajaran. Deepublish: Yogyakarta.

Mustari. M. (2017). Nilai Karakter Refleksi Untuk Pendidikan. PT Raja Grafindo Persada: Depok.

Semra. G.K \& Denzi. G.B. (2017). The Education of Developing Responsibility Value. Journal of Education and Training Studies. 5(2). 